\title{
Analisis Kualitas Hidup Pasien Usia Produktif Pengguna Gigi Tiruan Sebagian Lepasan di RSGM PSPDG Fakultas Kedokteran Universitas Sam Ratulangi Manado
}

\author{
Krista V. Siagian \\ Christy N. Mintjelungan \\ Program Studi Pendidikan Dokter Gigi \\ Fakultas Kedokteran Universitas Sam Ratulangi Manado \\ Email: parlinggoman.simatupang@yahoo.com
}

\begin{abstract}
Working-age population has a great potential in terms of productivity and creativity of work as well as health problems including oral and dental health that will affect the quality of life (QoL). This study was aimed to analyze the QoL of the productive age patients who wore partial removable dentures made at Dental and Oral Hospital (RSGM) Sam Ratulangi University in Manado. This was a descriptive analytical study with a cross sectional design. This study was conducted at Dental and Oral Hospital from March to October 2017. We used OHIP 14 questionnaire to assess the QoL. Data were statistically analyzed by using univariate, bivariate, and multivariate analysis. There were 30 respondents of working age (16-54 years) wearing partial removable dentures obtained by purposive sampling. The results of OHIP-14 showed that 25 respondents $(83.3 \%$ ) had good QoL and 5 respondents $(16.7 \%)$ had moderate QoL. The chi-square test showed a significant relationship between the duration of wearing denture and QoL ( $P$-value of 0.041). Conclusion: In this study, the quality of life of most working-age patients wearing partial removable dentures was good. There was a significant correlation between the duration of wearing denture and the quality of life based on OHIP-14. Keywords: productive age, partial removable denture, OHIP-14
\end{abstract}

\begin{abstract}
Abstrak: Populasi usia produktif memiliki potensi besar dalam hal produktivitas dan kreativitas bekerja, namun juga masalah kesehatan termasuk kesehatan gigi dan mulut yang akan memengaruhi kualitas hidup. Penelitian ini bertujuan untuk menganalisis kualitas hidup pasien usia produktif pengguna gigi tiruan sebagian lepasan (GTSL) yang dibuat di Rumah Sakit Gigi dan Mulut (RSGM) Program Studi Pendidikan Dokter Gigi (PSPDG) Fakultas Kedokteran Universitas Sam Ratulangi Manado. Jenis penelitian ialah deskriptif analitik dengan desain potong lintang. Penelitian dilaksanakan di RSGM PSPDG Fakultas Kedokteran Universitas Sam Ratulangi sejak bulan Maret sampai Oktober 2017. Instrumen penelitian ialah kuesioner OHIP 14 untuk menilai kualitass hidup. Data dianalisis secara univariat, bivariat dan multivariat. Responden dalam studi ini berjumlah 30 pasien usia produktif (16-54 tahun) pengguna GTSL yang dibuat di RSGM PSPDG Fakultas Kedokteran Universitas Sam Ratulangi, diperoleh dengan metode purposive sampling. Hasil penilaian dimensi OHIP-14 memperlihatkan 25 responden $(83,3 \%)$ dengan kualitas hidup baik dan 5 responden $(16,7 \%)$ dengan kualitas hidup sedang. Hasil uji chi-square terhadap hubungan antara lama pemakain GTSL dan kualitas hidup pasien pengguna GTSL mendapatkan nilai $P=0,041$. Simpulan: Kualitas hidup pasien pengguna GTSL di RSGM PSPDG Fakultas Kedokteran Universitas Sam Ratulangi berdasarkan OHIP-14 tergolong baik. Terdapat hubungan antara lama pemakaian GTSL dan kualitas hidup berdasarkan OHIP-14 pada pasien pengguna GTSL.
\end{abstract}

Kata kunci: usia produktif, gigi tiruan sebagian lepasan, kualitas hidup OHIP-14 
Usia produktif menurut Kamus Besar Bahasa Indonesia adalah usia ketika seseorang masih mampu bekerja dan menghasilkan sesuatu, yang umumnya berkisar 16-54 tahun. ${ }^{1}$ Data dari CIA World Factbook yang dikutip Indonesia-investments menyatakan bahwa terdapat $66,5 \%$ penduduk Indonesia dari 250 juta total populasi merupakan usia produktif. Angka ini menunjukkan dari perspektif demografis bahwa usia produktif di Indonesia bukan hanya memiliki potensi besar dalam hal produktifitas dan kreatifitas bekerja, namun juga permasalahan kesehatan termasuk kesehatan gigi dan mulut yang akan berpengaruh terhadap kualitas hidup, produktivitas dan kreativitas kerja. $^{2}$

Data kehilangan gigi pada usia produktif (16-54 tahun) menurut laporan Riskesdas (Riset Kesehatan Nasional) 2013 sebesar 25,9. ${ }^{3}$ Survei perusahaan obat perekat gigi palsu di Indonesia yaitu Glaxo Smith Kline $(\mathrm{GSK})^{4}$ melaporkan terdapat $14 \%$ usia produktif penduduk diatas 15 tahun merupakan pengguna gigi tiruan, Prevalensi kehilangan seluruh gigi pada dewasa muda di Meksiko sekitar 2,4\%.5 Menurut Dinas Kesehatan Kota Manado tahun 2012 sebanyak 1187 orang memperoleh tindakan pencabutan gigi di Kota Manado, sedangkan yang sudah menggunakan gigi tiruan $7,1 \% .{ }^{6}$ Hal ini menunjukkan bahwa banyak masyarakat usia produktif yang menderita kehilangan gigi dan sudah melakukan perawatan gigi tiruan.

Kehilangan gigi biasanya disebabkan oleh beberapa faktor, namun kebanyakan karena karies dan penyakit periodontal. Persentase keterlibatan karies dan penyakit periodontal terhadap kehilangan gigi tergantung pada usia. ${ }^{7,8}$ Menurut Bianco, pada kalangan usia lansia, kehilangan gigi biasanya terjadi karena penurunan fungsi gigi oleh faktor penuaan atau penyakit periodontal. Kehilangan gigi pada usia produktif disebabkan oleh banyak faktor, yaitu karies, trauma akibat kecelakaan, fraktur, malfungsi gigi akibat kebiasaan buruk misalnya bruxism, merokok, mengunyah sebelah sisi, mengunyah pinang, serta abrasi dan atrisi gigi. ${ }^{9}$
Umumnya masyarakat berpendapat bahwa hanya lansia yang cenderung ompong dan perlu memakai gigi tiruan. Namun sebenarnya, ketika terjadi kehilangan gigi, seseorang membutuhkan gigi tiruan untuk mengembalikan fungsi gigi yang hilang. Kehilangan gigi akan menimbulkan berbagai masalah terutama pada usia produktif, seperti menurunnya rasa percaya diri terutama pada kehilangan gigi depan, masalah pencernaan karena makanan tidak terkunyah dengan baik akibat gigi belakang yang sudah dicabut, penyusutan tulang rahang yang menyebabkan asimetri wajah, wajah mengendur sehingga tampak seperti lebih tua dari usia sebenarnya, dan fonetik yang tidak jelas. ${ }^{10-12}$

Perawatan gigi tiruan pada pasien yang kehilangan gigi terutama pasien usia produktif sangat penting karena akan menolong pasien dalam memperbaiki penampilan dan estetik wajah, mengembalikan kemampuan mengunyah makanan, memulihkan fungsi bicara, mengganti, memelihara dan mempertahankan kesehatan jaringan mulut yang sisa, memperbaiki relasi rahang,serta meningkatkan kualitas hidup. ${ }^{13}$

Kualitas hidup merupakan kesempatan individu untuk dapat hidup nyaman, mempertahankan keadaan fisiologis sejalan dengan keadaan psikologis dalam kehidupan sehari-hari. ${ }^{14-16}$ Quality of Life (QoL) berdasarkan definisi WHO adalah persepsi individu di kehidupan mereka dalam konteks kebudayaan dan norma kehidupan serta hubungannya dengan tujuan, harapan, standar dan perhatian mereka terhadap hidupnya. $^{16}$

Studi literarur oleh Gerritsen et al. ${ }^{11}$ menyebutkan bahwa hilangnya satu atau beberapa gigi dapat menyebabkan gangguan fungsi dan estetika yang dapat memengaruhi kualitas hidup seseorang. Kamala $^{10}$ meneliti hubungan kehilangan gigi dengan kualitas hidup terkait kesehatan gigi dan mulut pada pegawai yang usia produktif di Universitas Bung Hatta, dan menyatakan bahwa seseorang yang kehilangan 5-9 gigi mempunyai kualitas hidup yang buruk dan kehilangan $>10$ gigi mempunyai kualitas hidup yang sangat 
buruk. Studi Zainab et al. ${ }^{17}$ tentang prevalensi pemakaian gigi tiruan dan hubungannya terhadap kualitas hidup di Kota Bharu, Kelantan, Malaysia, mendapatkan bahwa pengguna gigi tiruan secara signifikan mempunyai kualitas hidup yang lebih baik dibanding yang tidak menggunakan gigi tiruan.

Namun kenyataannya gigi tiruan tidak selalu berfungsi dengan baik ketika digunakan. Berdasarkan survei awal yang dilakukan peneliti, gigi tiruan juga memberi pengalaman yang kurang menyenangkan bagi penggunanya. Beberapa orang merasa kurang nyaman ketika mengunyah karena gigi tiruannya terasa longgar, sering lepas, merasa kurang percaya diri karena warna gigi tiruannya berbeda dengan gigi aslinya, bahkan terkadang hanya memakai gigi tiruannya hanya saat keluar rumah karena takut terlepas pada waktu makan dan berbicara.

Rumah Sakit Gigi dan Mulut (RSGM) Program Studi Pendidikan Dokter Gigi Fakultas Kedokteran Universitas Sam Ratulangi (RSGM PSPDG FK Unsrat) merupakan satu-satunya Rumah Sakit Khusus Gigi dan Mulut di Kota Manado yang menyediakan pelayanan kesehatan gigi dan mulut termasuk pembuatan gigi tiruan yang dikerjakan oleh Dokter Gigi Muda yaitu mahasiswa Profesi Dokter Gigi yang dibimbing oleh pembimbing klinik. Pelayanan pembuatan gigi tiruan sebagian lepasan (GTSL) di Bagian Prostodontik RSGM PSPDG FK Unsrat dilakukan secara bertahap, dimulai dari penentuan indikasi kasus, pencetakan sampai dengan insersi gigi tiruan gigi tiruan di mulut pasien dan kontrol setelah pemasangan. Biasanya pembuatan gigi tiruan ini membutuhkan kunjungan berulang dari pasien ke Bagian Prostodontik RSGM PSPDG FK Unsrat. Rerata kunjungan pasien prostodontik setiap hari ialah 10 pasien atau rerata 200 kunjungan pasien setiap bulan.

Penelitian mengenai kualitas hidup pasien pengguna GTSL di RSGM Unsrat belum pernah dilakukan khususnya pada pasien usia produktif. Berdasarkan latar belakang tersebut maka peneliti tertarik menganalisis kualitas hidup pada pasien usia produktif pengguna GTSL di Rumah Sakit Gigi dan Mulut (RSGM) Program Studi Kedokteran Gigi Universitas Sam Ratulangi Manado.

\section{BAHAN DAN METODE PENELITIAN}

Jenis penelitian ini ialah deskriptif analitik dengan desain potong lintang. Penelitian dilaksanakan di RSGM PSPDG FK Unsrat sejak bulan Maret sampai Oktober 2017. Responden penelitian berjumlah 30 pasien pengguna GTSL yang dibuat di RSGM PSPDG FK Unsrat, diperoleh dengan metode purposive sampling. Instrumen penelitian yang digunakan ialah kuesioner OHIP-14.

Data hasil penelitian diolah, dianalisis, diedit dan ditabulasi dengan menggunakan kartu koding (coding card), kemudian data dianalisis secara statistik menggunakan program komputer. Data yang telah dianalisis disajikan dalam bentuk tabel untuk menilai kualitas hidup.

\section{HASIL PENELITIAN}

Tabel 1 menunjukkan karakteristik responden penelitian sejumlah 30 orang dalam usia produktif yaitu 16-54 tahun, terdiri dari 23 responden perempuan $(76,67 \%)$ dan 7 responden laki-laki $(23,3 \%)$. Kisaran usia terbanyak pada 16-25 tahun $(36,7 \%)$, diikuti oleh usia 46-55 tahun $(33,3 \%)$, dan 36-45 tahun (30\%). Responden terbanyak berpendidikan tingkat SMA (60\%), diikuti tingkat SMP (26,7\%). Lama pemakaian GTSL, terbanyak ialah kurang dari 1 tahun (80\%).

Tabel 2 memperlihatkan pada dimensi keterbatasan fungsional terdapat sebanyak 26 responden $(86,6 \%)$ memiliki kualitas hidup yang baik dan 4 responden $(13,4 \%)$ dengan kualitas hidup sedang. Dimensi OHIP-14 baik rasa sakit fisik, dimensi ketidaknyamanan psikis, ketidakmampuan fisik, ketidakmampuan psikis, keterbatasan sosial dan keterhambatan terlihat pada 25 responden $(83,3 \%)$ dengan kualitas hidup baik dan 5 responden $(16,7 \%)$ dengan kualitas hidup sedang. 
Tabel 1. Distribusi responden berdasarkan karakteristik usia, jenis kelamin, pendidikan, dan lama pemakaian GTSL

\begin{tabular}{lcc}
\hline Karakteristik & n & \% \\
\hline Usia (tahun) & & \\
$16-25$ & 11 & 36,7 \\
$36-45$ & 9 & 30,0 \\
$46-55$ & 10 & 33,3 \\
Jenis kelamin & & \\
Laki-laki & 7 & 23,3 \\
Perempuan & 23 & 76,7 \\
Pendidikan & & \\
SD & 4 & 13,3 \\
SMP & 8 & 26.7 \\
SMA & 18 & 60.0 \\
Lama pemakaian & & \\
GTSL (tahun) & & \\
$\quad$ < 1 & 24 & 80,0 \\
1-2 & 6 & 20,0 \\
Total & 30 & 100 \\
\hline
\end{tabular}

Tabel 3 memperlihatkan hubungan antara jenis kelamin dengan kualitas hidup responden. Sebagian besar responden baik yang berjenis kelamin laki-laki maupun perempuan mempunyai kualitas hidup baik dengan total 25 responden $(83,3 \%)$, sedangkan 5 responden $(16,77 \%)$ mempunyai kualitas hidup sedang. Hasil uji chisquare mendapatkan nilai $P=0,159$ yang menunjukkan tidak terdapat hubungan antara jenis kelamin dan kualitas hidup responden.

Tabel 4 memperlihatkan hubungan antara pendidikan dan kualitas hidup responden. Sebagian besar responden terutama yang berpendidikan SMA (60\%) mempunyai kualitas hidup baik. Hasil uji chi square mendapatkan nilai $P 0,006$ yang menunjukkan tidak terdapat hubungan antara pendidikan dan kualitas hidup responden.

Tabel 2. Distribusi kualitas hidup pasien pengguna GTSL di RSGM PSPDG FK Unsrat berdasarkan tujuh dimensi OHIP-14

\begin{tabular}{|c|c|c|c|c|c|c|c|c|c|c|}
\hline \multirow[t]{4}{*}{ No. } & \multirow[t]{4}{*}{ Dimensi OHIP-14 } & \multicolumn{8}{|c|}{ Kualitas Hidup } & \multirow[t]{3}{*}{ Total } \\
\hline & & \multicolumn{4}{|c|}{ Baik } & \multicolumn{4}{|c|}{ Sedang } & \\
\hline & & \multicolumn{2}{|c|}{ Laki-laki } & \multicolumn{2}{|c|}{ Perempuan } & \multicolumn{2}{|c|}{ Laki-laki } & \multicolumn{2}{|c|}{ Perempuan } & \\
\hline & & $\mathrm{n}$ & $(\%)$ & $\mathrm{n}$ & $\%$ & $\mathrm{n}$ & $\%$ & $\mathrm{n}$ & $\%$ & (n) \\
\hline 1 & $\begin{array}{l}\text { Keterbatasan } \\
\text { Fungsional }\end{array}$ & 5 & 16,7 & 21 & 69,9 & 2 & 6,7 & 2 & 6,7 & 30 \\
\hline 2 & Rasa sakit fisik & 5 & 16,7 & 20 & 66,6 & 2 & 6,7 & 3 & 10,0 & 30 \\
\hline 3 & $\begin{array}{l}\text { Ketidaknyamanan } \\
\text { psikis }\end{array}$ & 5 & 16,7 & 20 & 66,6 & 2 & 6,7 & 3 & 10,0 & 30 \\
\hline 4 & Ketidakmampuan fisik & 5 & 16,7 & 20 & 66,6 & 2 & 6,7 & 3 & 10,0 & 30 \\
\hline 5 & $\begin{array}{l}\text { Ketidakmampuan } \\
\text { psikis }\end{array}$ & 5 & 16,7 & 20 & 66,6 & 2 & 6,7 & 3 & 10,0 & 30 \\
\hline 6 & Keterbatasan sosial & 5 & 16,7 & 20 & 66,6 & 2 & 6,7 & 3 & 10,0 & 30 \\
\hline 7 & Keterhambatan & 5 & 16,7 & 20 & 66,6 & 2 & 6,7 & 3 & 10,0 & 30 \\
\hline
\end{tabular}

Tabel 3. Hubungan jenis kelamin dan kualitas hidup pasien pengguna GTSL di RSGM PSPDG Unsrat

\begin{tabular}{lcccc}
\hline Jenis kelamin & \multicolumn{2}{c}{ Kualitas hidup } & Total & P \\
& $\begin{array}{c}\text { Baik } \\
\mathrm{n}(\%)\end{array}$ & $\begin{array}{c}\text { Sedang } \\
\mathrm{n}(\%)\end{array}$ & & \\
\hline Laki - Laki & $5(16,7)$ & $2(6,7)$ & $7(23,4)$ & \\
Perempuan & $20(66,6)$ & $3(10,0)$ & $23(76,6)$ & 0,159 \\
Total & $25(83,3)$ & $5(16,7)$ & $30(100)$ & \\
\hline
\end{tabular}


Siagian, Mintjelungan: Analisis kualitas hidup pasien usia produktif...

Tabel 4. Hubungan pendidikan dengan kualitas hidup pasien pengguna pengguna GTSL di RSGM PSPDG Unsrat

\begin{tabular}{lcccc}
\hline Pendidikan & \multicolumn{2}{c}{ Kualitas hidup } & Total & P \\
& $\begin{array}{c}\text { Baik } \\
\mathrm{n}(\%)\end{array}$ & $\begin{array}{c}\text { Sedang } \\
\mathrm{n}(\%)\end{array}$ & & \\
\hline SD/Tidak sekolah & $3(10,0)$ & $1(3,4)$ & $4(13,4)$ & \\
SMP & $4(13,3)$ & $4(13,3)$ & $23(26,6)$ & 0,006 \\
SMA & $18(60,0)$ & $0(0,0)$ & $18(60)$ & \\
Total & $25(83,3)$ & $5(16,7)$ & $30(100)$ & \\
\hline
\end{tabular}

Tabel 5 memperlihatkan hubungan antara usia dan kualitas hidup responden. Sebagian besar responden dari ketiga kelompok usia memperlihatkan kualitas hidup baik. Hasil uji chi-square mendapatkan nilai $P=0,159$ yang menunjukkan tidak terdapat hubungan antara usia dan kualitas hidup responden.

Tabel 6 memperlihatkan hubungan antara lama pemakaian GTSL dan kualitas hidup. Sebagian besar responden memiliki kualitas hidup yang baik terutama responden yang memakai gigi tiruan <1 tahun yaitu sebanyak 22 responden (73,3\%). Hasil uji chi-square mendapatkan nilai $P=0,041$ yang menunjukkan terdapat hubungan antara lama pemakain GTSL dan kualitas hidup responden.

Tabel 5. Hubungan usia dan kualitas hidup pasien pengguna pengguna GTSL di RSGM PSPDG Unsrat

\begin{tabular}{ccccc}
\hline $\begin{array}{c}\text { Usia } \\
\text { (tahun) }\end{array}$ & $\begin{array}{c}\text { Kualitas hidup } \\
\text { Baik } \\
\mathrm{n}(\%)\end{array}$ & $\begin{array}{c}\text { Sedang } \\
\mathrm{n}(\%)\end{array}$ & Total & $\boldsymbol{P}$ \\
\hline $25-35$ & $11(36,7)$ & $0(0)$ & $11(36,7)$ & \\
$36-45$ & $7(23,3)$ & $2(6,7)$ & $9(30,0)$ & 0,159 \\
$46-54$ & $7(23,3)$ & $3(10,0)$ & $10(33,3)$ & \\
Total & $25(83,3)$ & $5(16,7)$ & $30(100)$ & \\
\hline
\end{tabular}

Tabel 6. Hubungan lama pemakain GTSL dan kualitas hidup pasien pengguna GTSL di RSGM Unsrat

\begin{tabular}{lllll}
\hline $\begin{array}{l}\text { Lama pemakaian } \\
\text { GTSL (tahun) }\end{array}$ & $\begin{array}{c}\text { Kualitas Hidup } \\
\text { Baik } \\
\mathrm{n}(\%)\end{array}$ & $\begin{array}{c}\text { Sedang } \\
\mathrm{n} \%\end{array}$ & Total & P \\
\hline$<1$ & $22(73,3)$ & $2(6,7)$ & $24(80,0)$ & \\
$1-2$ & $3(10,0)$ & $3(10,0)$ & $6(20,0)$ & \\
Total & $25(83,3)$ & $5(16,7)$ & $30(100)$ & 0,041 \\
\hline
\end{tabular}

\section{BAHASAN}

Penelitian ini menunjukkan bahwa jumlah responden penelitian perempuan lebih banyak daripada laki-laki (Tabel 1). Pasien pengguna GTSL usia produktif yang membuat gigi tiruan di RSGM PSPDG Unsrat yang berjenis kelamin perempuan jauh lebih banyak daripada laki-laki. Hal ini mungkin disebabkan karena perempuan umumnya lebih peduli terhadap estetika termasuk penampilan. Selain itu, perbedaan jumlah responden yang cukup mencolok antara kedua jenis kelamin dapat disebabkan karena sebagian besar responden perempuan lebih memilih menetap di rumah sebagai ibu rumah tangga daripada bekerja di luar sedangkan responden lakilaki sebagian besar memilih bekerja 
sebagai pegawai di sektor formal pada jam kerja. Dengan demikian responden perempuan lebih berpeluang berobat ke RSGM PSPDG FK Unsrat karena memiliki waktu untuk berobat di pagi sampai siang hari mengingat jam pelayanan dibuka mulai jam 08.00-14.00. Hasil penelitian ini sejalan dengan penelitian oleh Agniti ${ }^{18}$ pada tahun 2010 tentang persentase pengguna gigi tiruan di Indonesia yang juga mendapatkan persentase pengguna gigi tiruan berjenis kelamin perempuan lebih banyak dibandingkan laki-laki.

Hasil penelitian juga menunjukkan bahwa kelompok usia responden paling banyak pada kelompok usia produktif muda 16-25 tahun (36,7\%) (Tabel 2). Kehilangan gigi pada usia muda di Kota Manado mungkin disebabkan karena pola hidup suka makan makanan manis dan asam seperti asinan khas kota Manado (gohu), junk food seperti snack dan yang tidak memiliki efek cleansing pada rongga mulut, dan perilaku malas menyikat gigi. Faktor risiko karies gigi memiliki hubungan sebab akibat terjadinya karies gigi atau faktor yang mempermudah terjadinya karies gigi. Beberapa faktor yang dianggap sebagai faktor risiko ialah pengalaman karies gigi, kurangnya penggunaan fluor, oral higiene yang buruk, jumlah bakteri, saliva, serta pola makan dan jenis makanan. ${ }^{19}$

Data hasil penelitian juga menunjukkan bahwa sebagian besar responden menempuh pendidikan tingkat SMA (60\%) (Tabel 2). Pendidikan juga memengaruhi pengetahuan dan perilaku seseorang. Pengetahuan yang baik membuat responden lebih peduli terhadap kesehatan gigi dan mulut serta penampilan. Kehilangan gigi juga dipengaruhi oleh pengetahuan responden terhadap pemeliharaan kesehatan gigi dan mulut. Pemeliharaan kesehatan gigi dan mulut yang kurang akan lebih mudah menyebabkan kerusakan dan tanggalnya gigi sehingga gigi yang tanggal harus digantikan dengan gigi tiruan untuk mengembalikan fungsi yang hilang.

Data tentang lamanya pemakaian GTSL pada penelitian ini paling banyak pada $<1$ tahun (Tabel 2). Responden dalam penelitian ini merupakan pasien yang kebanyakan dibawa oleh mahasiswa coass Kedokteran Gigi Unsrat untuk memenuhi kebutuhan kasus (requirement) agar dapat menjadi dokter gigi, sehingga sulit untuk meminta pasien kembali datang ke RSGM Unsrat untuk dijadikan responden penelitian.

Penelitian ini menunjukkan bahwa kualitas hidup responden baik untuk 7 dimensi OHIP-14 (Tabel 2). Pada dimensi keterbatasan fungsional, sebanyak $86,6 \%$ responden memiliki kualitas hidup yang baik, sedangkan kualitas hidup sedang sebanyak 13,4\%. Dimensi OHIP-14 baik rasa sakit fisik, dimensi ketidaknyamanan psikis, ketidakmampuan fisik, ketidakmampuan psikis, keterbatasan sosial dan keterhambatan terlihat pada $83,3 \%$ responden dengan kualitas hidup baik, sedangkan kualitas hidup sedang sebanyak 16,7\% responden. Sejalan dengan penelitian yang dilakukan di Makassar oleh Berutu et al. ${ }^{20}$ menyatakan bahwa masih ada yang mengeluh untuk dimensi ketidakmampuan fisik serta rasa sakit fisik karena ada ketidakpuasan dan rasa tidak nyaman dalam hal mastikasi, Beberapa responden mengeluhkan gigi tiruan rahang bawahnya longgar, sehingga terkadang sulit untuk mengunyah makanan serta kemampuan pengunyahan yang berbeda dengan ketika masih menggunakan gigi asli. Penelitian oleh Perea et al. ${ }^{21}$ juga melaporkan bahwa penggunaan gigi tiruan memberikan dampak negatif terhadap kualitas hidup pasien terutama pada dimensi keterbatasan fungsional dan rasa sakit fisik akibat gigi tiruan pada rahang bawah yang goyang dan gampang lepas.

Penelitian ini menunjukkan hubungan tidak bermakna antara jenis kelamin dan kualitas hidup responden. Hasil ini tidak sejalan dengan penelitian oleh Henniwati yaitu perempuan lebih cenderung merasakan sakit sehingga berpengaruh pada kualitas hidupnya sedangkan laki-laki lebih mementingkan dan memperhatikan kualitas hidupnya terutama kesehatan. ${ }^{22}$ Begitupun penelitian dari Sadock menunjukkan kuali- 
tas hidup laki-laki jauh lebih baik dibandingkan perempuan karena adanya prevalensi depresi dan kecemasan lebih besar pada perempuan dari pada laki-laki sebab terdapat perbedaan sekresi hormon, tekanan psikososial, dan tipe perilaku antara laki-laki dengan perempuan. ${ }^{23}$

Hasil penelitian ini menunjukkan terdapat hubungan tidak bermakna antara pendidikan dan kualitas hidup responden $(P$ $>0,05$ ) (Tabel 4). Hal ini mugkin disebabkan pengalaman individu dan latar belakang kultural serta kemampuan adaptasi yang memiliki peran lebih besar daripada pendidikan formal.

Terdapat hubungan yang tidak bermakna antara usia dan kualitas hidup responden $(P=0,159)$ (Tabel 5). Penelitian yang dilakukan Hanin et al. ${ }^{24}$ menyebutkan pertambahan usia tidak serta merta berkaitan dengan penurunan kualitas hidup dari pengguna gigi tiruan bila perancu seperti pola gigi yang hilang dan pemakaian gigi tiruan dapat dikendalikan, sehingga keluhan dan kecemasan lebih sedikit dari responden berusia muda yang sadar keadaan rongga mulutnya.

Pada penelitian ini terdapat hubungan bermakna antara lama pemakaian GTSL dan kualitas hidup $(P \leq 0,05)$ (Tabel 6). Hal ini terjadi karena GTSL yang digunakan dalam rongga mulut lama-kelamaan menjadi semakin longgar yang disebabkan berkurangnya dukungan tulang di bawah permukaan gusi dan perubahan bentuk mulut, sehingga kecekatan gigi tiruan juga akan berubah dan semakin tidak nyaman dipakai yang memengaruhi kualitas hidup penggunanya. Hasil penelitian ini tidak selaras dengan penelitian Ummul $^{25}$ di Makassar yang melaporkan bahwa berdasarkan lamanya penggunaan gigi tiruan, responden yang telah menggunakan gigi tiruan selama $>5$ tahun mempunyai kualitas hidup yang lebih baik dibanding yang menggunakan gigi tiruan penuh $<5$ tahun. Hal ini bisa diakibatkan karena faktor adaptasi yang lebih baik pada responden yang telah lebih lama menggunakan gigi tiruan.

\section{SIMPULAN}

Berdasarkan hasil penelitian dapat disimpulkan bahwa kualitas hidup pasien pengguna GTSL di RSGM FK Unsrat berdasarkan OHIP-14 tergolong baik. Terdapat hubungan bermakna antara lama pemakaian GTSL dan kualitas hidup berdasarkan OHIP-14 pada pasien pengguna GTSL di RSGM FK Unsrat.

\section{SARAN}

1. Diharapkan RSGM PSPDG FK Unsrat, Dinas Kesehatan dan puskesmas dapat menggunakan informasi dalam penelitian ini untuk kepentingan promosi kesehatan tentang pelayanan gigi tiruan di sarana ini untuk meningkatkan kualitas hidup masyarakat.

2. Diharapkan dengan pemberian informasi tersebut, masyarakat yang kehilangan gigi dapat termotivasi untuk berobat ke RSGM PSPDG FK Unsrat dalam perawatan gigi tiruan.

3. Perlu dilakukan penelitian sejenis dengan melibatkan populasi yang lebih luas untuk memperoleh hasil yang lebih akurat.

\section{DAFTAR PUSTAKA}

1. Kamus Besar Bahasa Indonesia. [Online]. [cited 2016 April]. Available from: http: //bahasa.kemdiknas.go.id/kbbi/ index.php.

2. Indonesia - The World Factbook. [cited 2016 April]. Available from: https://www. cia.gov/library/publications/the-world factbook/geos/id.html

3. Departemen Kesehatan Republik Indonesia. Laporan Riset Kesehatan Dasar Nasional. Jakarta: Badan Penelitian dan Pengembangan Kesehatan, 2013.

4. Glaxo Smith Kline (GSK). 14\% Masyarakat Indonesia Pengguna Gigi Tiruan (artikel). Available from: http://www. pdpersi.co.id/content/news.php?mid=5 \&nid $=649$ \& catid $=23$

5. Medina-Solis CE, Perez-Nunez R, Maupome G, Casanova-Rosado JF. Edentulism among Mexican adults aged 35 years and older and associated factors. Am J Public Health. 2006;96(9):1578-81.

6. Dinas Kesehatan Kota Manado. Profil 
kesehatan Kota Manado. Manado: 2012. [cited 2015 Jun 15]. Available from: URL: http://www.depkes.go.id

7. Gunadi HA, Margo A, Burhan LK, Surya T, Setiabudi I. Buku Ajar Gigi Geligi Tiruan Sebagian Lepasan jilid 1 . Jakarta: Hipokrates, 2012.

8. Widyanti S. Pencegahan penyakit gigi dan mulut guna meningkatkan kualitas hidup. Pidato Pengukuhan Jabatan Guru Besar diucapkan di depan rapat terbuka Universitas Gadjah Mada. Yogyakarta, 2009.

9. Setyadi DA. Analisis Pengaruh Faktor Hilangnya Gigi Pasien Menggunakan Metode Regresi Logistik Berbasis Komputer. Jakarta: Universitas Bina Nusantara, 2011.

10. Kamala AI. Hubungan kehilangan gigi dengan kualitas hidup terkait kesehatan gigi dan mulut pada pegawai paruh baya di Universitas Bung Hatta [Skripsi]. Padang: Universitas Andalas; 2014.

11. Gerittsen AE, Allen P, Witter D, Bronkhorst EM, Creugers NH. Tooth loss and oral health-related quality of life: a systematic review and metaanalysis. Health Qual Life Outcomes. 2010;8:126.

12. Huzain SZ, Shujaat NG, Idris SH. Oral health related quality of life (OHRQoL) in 40-70 years. Pak Oral Dental J. 2010:30(2):530.

13. Emini. Gigi tiruan dan perilaku ibadah. Jurnal Health Quality. 2013;4(1):28-31.

14. Huzain SZ, Shujaat NG, Idris SH. Oral health related quality of life (OHRQoL) in 40-70 years. Pak Oral Dental J. 2010: 30(2):530.

15. Pradono J, Hapsari D, Sari P. Kualitas hidup penduduk Indonesia menurut International Classification of functioning, disability and health (ICF) dan faktor-faktor yang mempengaruhinya (Analisis Lanjut Data RIKESDAS 2007). Bul Penelit Kesehat. 2009; Supplement:1-10.

16. Skevington SM, Lotfy M, O'Connell KA. The World Health Organization's WHOQOL-BREF quality of life assessment: psychometric properties and results of the International Field
Trial a report from the WHOQOL Group. Qual Life Res.2004;13:299310.

17. Zainab S, Ismail NM, Nobanee TH, Ismail AR. The prevalence of denture wearing and the impact on the oral health related quality of life among elderly in Kota Bharu, Kelantan. AOS. 2008: 3(1):17-22.

18. Aginiti MD. Persentase pengguna gigi tiruan di Indonesia. Media Litbang Kesehatan. 2010;XX(2):50-8.

19. Sondang P, Hamada T. Menuju Gigi dan Mulut Sehat Pencegahan dan Pemeliharaan Terbitan 1. Medan: USU Press, 2008.

20. Berutu M, Dharmautama. Kualitas hidup manula pengguna GTL berdasarkan OHIP-14. Jurnal Dentofasial. 2015; 14(1):55-60.

21. Perea C, Suarez-Gracia M-J, Del Rio J, Torres-Lagares D, Montero J, CastilloOyague R. Oral health-related quality of life in complete denture wearers depending on their socio-demographic background, prosthetic-related factors and clinical condition. Med Oral Patol Oral Cir Bucal. 2013;18(3):e371-80.

22. Handayani D, Wahyuni. Hubungan dukungan keluarga dengan kepatuhan lansia dalam mengikuti posyandu lansia di posyandu lansia Jetis Desa Krajan Kecamatan Weru Kabupaten Suko-harjo. Jurnal Kesehatan Gaster. 2011;2(1):4950.

23. Amurwaningsih M, Uswatun Nisaaa, Daryono A. Analisis hubungan kualitas hidup yang berhubungan dengan kesehatan mulut (OHRQoL) dan status kecemasan dengan status nutrisi pada masyarakat usia lanjut. Majalah Ilmiah Sultan Agung. 2010;48(123):4-5.

24. Hanin I. Hubungan Kemampuan Mastikasi (Analisa Menggunakan Alat Ukur Kemampuan Mastikasi) Dengan Kualitas Hidup Wanita Pra-Lansia Dan Lansia, Tesis, Fakultas Kedokteran Gigi Universitas Indonesia.2012, Jakarta

25. Ummul R. Perbedaan kualitas hidup manula pengguna dan bukan pengguna gigi tiruan penuh di Kota Makassar [Skripsi]. Makasar: Universitas Hasanuddin; 2014. 